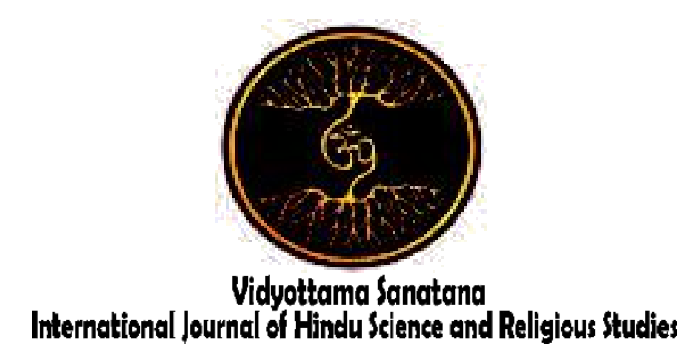

Vol. 5 No. 2 October 2021

\title{
CHARACTER EDUCATION THROUGH MATERUNA NYOMAN CEREMONY IN TENGANAN PEGRINGSINGAN VILLAGE, KARANGASEM-BALI
}

\author{
By: \\ I Wayan Saklit' ${ }^{1}$ I Wayan Sukayasa ${ }^{2}$, I Wayan Winaja ${ }^{3}$ \\ ${ }^{1,2,3}$ Hindu University of Indonesia \\ E-mail: ${ }^{1}$ saklitiwayan@gmail.com
}

\begin{tabular}{|l|l|l|} 
Received: August 21, 2020 & Accepted: August 23, 2020 & Published: October 31, 2020
\end{tabular}

\begin{abstract}
This research aims to study the phenomenon of character education through the Materuna Nyoman Ceremony in Tenganan Pegringsingan Village, Karangasem Regency, Bali Province. This research was conducted using a qualitative approach and found results, such as (1) the Materuna Nyoman ceremony is a ceremony that must be followed by every youth in Tenganan Pegringsingan Village as a requirement of being recognized as an adult; (2) through the Materuna Nyoman Ceremony, religious characters, patience, care for the environment, social care, responsibility, independence, and self-sacrifice can be formed; and (3) the participation of teruna in the Materuna Nyoman Ceremony has implications for increasing the teruna's knowledge of ethics, responsibility, social care, environmental care, and so on. The development of positive knowledge evidently also has implications for the formation of good attitudes, and ultimately leads to the development of good behavior for teruna who have participated in the Materuna Nyoman Ceremony.
\end{abstract}

Keywords: Ceremony, Materuna Nyoman, Character Education 


\section{INTRODUCTION}

A challenge that is very influential in the world of education in the global era is the modern lifestyle that tends to be materialistic and individual, so the education world is needed not only to teach intellectuals but also to shape the character of students. Therefore we need an education system which contains character values that can be carried out through formal and nonformal education. Character education can also be done through culture, as has been done by the people of Tenganan Pegringsingan Village.

For the people of Tenganan Pegringsingan Village who until now still maintain tradition, character education based on local wisdom for teenagers is very necessary, because on the shoulders of teenagers the hope of cultural preservation is placed. Therefore, the character building of adolescents is very important to get attention. Educating the character of the teruna has been carried out by the people of Tenganan Pegringsingan Village from generation to generation through the "Materuna Nyoman Ceremony" as a condition to be recognized as adults and allowed to marry. The community believes that through the Materuna Nyoman Ceremony the character of the teruna can be formed so they grow into human characters, and in the end they are able to maintain the tradition that grows and develops in Tenganan Pegringsingan Village.

Character education through rituals is also described by Syarif et al. (2016), that traditional ceremonies as collective rituals have a role in maintaining the collective existence of indigenous peoples, therefore the younger generation is expected to have awareness of their own cultural wealth. The article was also the background for the author's interest in exploring more deeply the character education through the Materuna Nyoman Ceremony which was carried out by the people of Tenganan Pengringsingan Village.
Research about the education of the Nyoman Materuna Ceremony in Tenganan Pegringsingan Village has also been conducted by Arta \& Yuliartini (n.d.). However, it is limited only describing, while this research covers a broader subject, namely exploring the implications of the Materuna Nyoman Ceremony as character education for adolescents. Therefore, the problem that is explored in this study is the process of character building through the Materuna Nyoman Ceremony, and its implications for the attitudes and behavior of teruna.

\section{METHOD}

The focus of this research is to analyze the phenomenon of character education in Tenganan Pegringsingan Village. This research aims to understand the phenomenon of what has been experienced by research subjects, so this research was designed using qualitative research (Moleong, 2010, p. 54). Because this research is a qualitative research, it relies heavily on direct interpretation of events in the field (Stake, 2010, p. 54).

The main research data is primary data, namely data relates to character education through the Materuna Nyoman Ceremony which is obtained directly in the field. Apart from primary data, this research is also supported by secondary data obtained through literature review. Data collection was carried out through observation, interviews and documentation. Data analysis was performed using the interactive technique of Miles \& Huberman, which is a process that involves data collection, data reduction, data presentation, and drawing conclusions/verification that has been done interactively (Miles \& Huberman, 1992, p. 19).

III. RESULTS AND DISCUSSION

3.1 Implementation of the Meteruna Nyoman Ceremony

The Materuna Nyoman Ceremony is a ritual that carried out by the Tenganan 
Pegringsingan community to mature a child. This means that a young man is not considered an adult before completing the Materuna Nyoman Ceremony, even though he is biologically mature, and is not allowed to marry. If it is violated, he will get a penalty, namely being expelled from the traditional village. The Materuna Nyoman Ceremony can be carried out if it has met the requirements, namely that the participants have represented the three patemu (Patemu Kaja, Patemu Tengah, and Patemu Kelod). The series of the Materuna Nyoman Ceremony, as follows:

\subsubsection{Preparation Phase.}

The previously various ceremonies have been done, before the main ceremony of Meteruna Nyoman are held, they are: Majak-ajakan, Malali, and Mabase pamit. Majak-ajakan is the stage of introducing the duties of a teruna, and building an agreement between parents who have children who are around ten years old, to carry out the Meteruna Nyoman Ceremony. Malali is praying or performing meditation at temples in Tenganan Pegringsingan Village once every three days with the aim of requesting that the Materuna Nyoman Ceremony receive the blessing and grace of Sesuhunan (who is praised), so that the ceremony can run smoothly. This ritual is considered pingit (not allowed to be known by other people), so it is done at midnight and when entering the temple it is not allowed to go through the temple gate. Mabase pamit is a ritual of bringing the base pamit (betel leaf and areca nut) to Puseh Temple, carried out the day before Padewasan as a symbol of asking goodbye to end the Malali ritual and continuing to the Padewasan ceremony stage, and since then all students are required to live in subak (dorm) for one year. The purpose of the preliminary ceremony is to strengthen the mentality of candidate students who will attend education and ask God's blessing so that the teruna can complete their education.

\subsubsection{The Main Ceremony}

The main ceremony is a ritual maturing process, which the community of Tenganan Pegringsingan village analogizes as the metamorphosis of a caterpillar into a butterfly. The main series of ceremonies are: Kagedong, Matamyang and Malegar. Kagedong is a ceremony where Teruna Nyoman is analogous to a cocoon that is doing tapa and tending to pingit. Kagedong begins with prayers at the Dalem Pengastulan temple and Dewi Sri temple. Continued with megundul, metatah and mekala-kalan as symbols of self cleansing before entering the gedong. After mabersih, Teruna Nyoman will enter the gedong and be asked to tour the village, proceed to the gantih (home for young women organizations) to participate in the Matimpugan ritual in the three gantih (Gantih Wayah, Gantih Nengah, and Gantih Nyoman). At this ceremony the daha sits on the bale buga (a sanctified building) and covers the whole body with a cloth. Then Teruna Pengawin will throw the daha with mud made from a mixture of buffalo dung and ripe jackfruit. During the Matimpugan ritual, Teruna Nyoman who is in the gedong must be silent because he is in a state of samadhi, while listening to Teruna Bani masambodana (saying the typical invocation of Tenganan Pegringsingan). This ceremony aims to show the patience of the daha who sit quietly, make no sound, and are not angry, even though they have to endure the nausea and pain caused by the throwing of the teruna to their bodies.

Matamyang is a ritual that analogizes Teruna Nyoman as partially born cocoons, so they bring tamyang (shields) to cover their bodies while they go around the village and visit gantih to attend Masambodana Maidih-idihan. Unlike the Matimpugan, this time masambodana was not only pronounced by Teruna Bani but also by Teruna Pengawin. At the Masambodana event, Teruna Nyoman will witness the patience of the teruna, waiting for the daha's answer to be able to continue 
the Sambodana. If it is not answered, the teruna must be patient and must repeat the Sambodana until daha gives an answer, as a sign that daha has forgiven the mistakes that have been made at the time of Matimpugan. This ceremony aims to teach patience to Teruna Nyoman.

Malegar is a ritual as a symbol that Teruna Nyoman or the cocoon is fully born. At the Malegar ceremony, Teruna Nyoman is ushered around the village and visiting gantih to attend the Masambodana Maidihidihan event. At the time of Malegar, Teruna Nyoman did not use tamyang to cover her body, as a symbol that the butterfly was fully born. The ritual that is carried out at the Malegar ceremony is the same as at the Matamyang time.

\subsubsection{The Final Phase}

The final stage of the Materuna Nyoman Ceremony is Ngejot katipat, Ngintarang katekung, Namyu katamyu and Ngejot gede which is held at Sasih Kasanga and ends with the Katinggal Ceremony which is held at Purnama Kaulu. Ngejot katipat, done by daha to give food to Teruna Nyoman in the form of ketupat as a thank-you note for participating in the Matimpugan Ceremony.

Ngintarang Katekung is Teruna Nyoman who go around the village of Tenganan Pegringsingan to pray at each temple in the outer area of Tenganan Pegringsingan Village. In addition to praying, this ritual also aims to increase the teruna's horizone into the environment, such as: regional boundaries and temples in Tenganan Pegringsingan Village, as well as natural resources, such as: rice fields, fields and forests along with their contents that belong to the village which must be managed properly for the welfare of the villagers.

Namyu katamyu is an activity for Teruna Nyoman to entertain Mekel, Teruna Bani, Teruna Pangawin, Teruna Panegenan Base and daha as a thank-you note for the guidance during the ceremony. Furthermore, daha also entertains Teruna
Nyoman as a reward for the meal that daha has received.

The last ritual related to the Materuna Nyoman Ceremony before Katinggal is Ngejot gede, namely Teruna Nyoman giving food to daha as a thank-you note for guiding Teruna Nyoman during the ceremony. Then jotan will be rewarded by daha in return with the same amount given by Teruna Nyoman. It is called Ngejot gede because of the large amount and type of food that has been carried.

The Katinggal Ceremony is the closing ceremony of the Materuna Nyoman Ceremony process, which indicates that students are considered to have sufficient knowledge to continue life in the community. In this ritual, the teruna will be given advice by the mekel as a provision to continue their education in the community. With the completion of the Katinggal Ceremony, the series of Materuna Nyoman Ceremony has been completed

Tenganan Pagringsingan community believes that the Materuna Nyoman ceremony is not only limited to rituals, but also a medium for character education. This can be understood because through the Materuna Nyoman Ceremony, the teruna are not only taught to know the character values, but what is more important is to practice these values in everyday life. Etzioni states that simply knowing what is right is not a guarantee that a person will do it and incorporate these values into his life (Schwartz et al., 2002, p. 133). The Materuna Nyoman ceremony is also used as a media to increase the closeness of the relationship between teruna, so that cooperation in the preservation of customs and culture can be materealized, as Robertson said that religious ceremonies have a function to intensify community solidarity (Koentjaraningrat, 2007, p. 67). Andrew Lang views religion as a cultural and sociohistorical phenomenon (Dillon, 2012, p. 691). Likewise, the Meteruna Nyoman Ceremony for the people of Tenganan Pegringsingan Village is a religion that can be viewed as a cultural 
phenomenon, because the ceremony has been cultivated from generation to generation.

The adherence of the Tenganan Pegringsingan community to maintain a culture of character education non-formally shows that they believe that people's life can only be understood through local culture. Benedict also argued that culture is the key to understand humankind (Pals, 1996 , p. 403). This means that to make teruna aware of their obligations, it must be done through education based on local culture, namely the Materuna Nyoman Ceremony. Koentjaraningrat also stated that culture is the entire system of ideas and tastes, actions, and works produced by humans in social life which belong to the community through learning (Koentjaraningrat, 2014, p.72). And the form of culture is a patterned behavior and actions (Koentjaraningrat, 2014). The decision of the Tenganan Pegringsingan community to educate character through ceremonies is also a patterned and structured action that is carried out continuously. Religious ceremonies are a form of following literary orders or scriptures as a form of carrying out certain disciplines (Mishra et al., 2008, p. 748). Likewise, the Materuna Nyoman Ceremony aims to instill self-discipline in Teruna Nyoman.

\subsection{The Character Building through Materuna Nyoman Ceremony}

Unlike the maturation ceremonies that carried out by Hindus in Bali, such as the Menek kelih or Raja Sewala ceremony, maturation through the Materuna Nyoman Ceremony is not only limited to rituals, but also learning in a dormitory for one year, as well as involving students in traditional and religious activities in the community. This shows that the aim of the Materuna Nyoman Ceremony is not only limited to rituals, but also aims to instill character values through ceremonial practice. Thus, it can be interpreted that the Materuna Nyoman Ceremony is a non-formal learning model to form human beings with character, who are not only cognitively capable, but also have sradha and bhakti, have noble character, are independent and responsible.

Excerpting Lickona's words, Koesoema (2012, p. 162) said that character education is more related to how virtue is practiced, not just being understand or understood as knowledge. Furthermore, according to Lickona (2012, pp. 85-100) to form good character and values, integrated education must be carried out which involves three components, namely moral knowing which fills more in the realm of cognitive, moral feeling which fills and strengthens the affection aspects of the individual being a human with good character, and moral acting is the result of the other two components of the character. Meanwhile, Śivānanda (1997, p.62) explains that it is thought that forms character, so that if someone shows noble thoughts, he will develop noble characters, and vice versa.

Referring to Lickona and Śivānanda's opinion above, it can be understood that to build good character, it is not enough only to provide knowledge of good values, but children must also be able to understand and have thoughts and desire to implement them and finally be able to implement good values in social life. In the Materuna Nyoman Ceremony, the three components have been designed through the ceremonial stages and activities carried out in the dormitory and in the traditional village. Based on data analysis, several characters were found that could be formed through the Materuna Nyoman Ceremony, as follows:

\subsubsection{Religious Character}

Religious is a character value in relation to God (Mustari, 2017, p. 1). Titib \& Sapariani (2007, p. 37), states that faith is an attitude and behavior that shows belief in the power of the Creator accompanied by obedience in following orders and staying away from His prohibitions. 
The religious character in the Materuna Nyoman Ceremony, is formed through ceremonies, such as: Malali, namely performing prayers or tapa to a temple at midnight for eight months; Mabase pamit, that is, praying at midnight to ask goodbye to end the Malali ritual and ask that the next ceremony run smoothly; Kagedong, is begun with cleaning by means of megundul and matatah, then enters the gedong and goes around the village, then continues to gantih to follow the Matimpugan ritual. While inside the gedong, Teruna Nyoman was not allowed to speak because at that time they were doing asceticism; Ngintarang Katekung, namely Teruna Nyoman was invited to pray to the temples in the outer area of Tenganan Pegringsingan Village. In addition, Teruna Nyoman is also required to attend ceremonies conducted by traditional villages, such as Usaba Kasa and Usaba Sambah.

These activities are believed to be able to form a religious character, because all of these activities are related to the attitude of sraddha and bhakti to God. Sraddha is a teenager's belief in the existence of God who is sitting in the temples of Tenganan Pegringsingan Village. The devotional attitude is shown by making prayers. Durkheim said that religious is something that is beyond the ability of human understanding, which cannot be grasped by reason and absorbed by the senses (Durkheim, 2011, p. 49). Likewise, the dewa who bersthana in every temple in Tenganan Pegringsingan Village could not be understood by the teruna through reason alone. He will be understood by performing prayers. Religious character also means belief in the law of karma, that is, every action will have its consequences, such as good or bad actions that are done at that time will be punished at that time, which is called Prarabda Karma Phala (Sudiani, 2017, p.65). Therefore, the teruna are also directed to always do good in order to get good results.
By directing Teruna Nyoman to do good deeds, such as those practiced in the Malali ritual, Ngintarang katekung and ceremonial activities, encourages children to manifest religious behavior. This is in accordance with Mulyasa (2011, p. 166), that the habituation method to teach students to get used to praiseworthy, sincere, and honest behavior. By getting used to good qualities as routine, students can carry out these habits without losing a lot of energy and without much difficulty (Arifin \& Rusdiana, 2019, p. 170).

\subsubsection{Environmental Concern Character}

The character of caring for the environment is an attitude and actions that always strive to prevent damage to the natural environment around it, and develop efforts to repair natural damage that has occurred (Samani \& Hariyanto, 2012, p. 52). The formation of the character of caring for the environment through the Materuna Nyoman Ceremony is found in the Ngintarang Katekung ritual, which is inviting Teruna Nyoman to tour the Tenganan Pegringsingan Village area. Asking Teruna Nyoman to observe directly the boundaries of the area means that he has provided insight into the boundaries of the area, the size of the area and the villages that border the Tenganan Pegringsingan Village area. Likewise, asking Teruna Nyoman to enter the forest is a way to instill the importance of forests for human survival, because in the forest they can recognize various kinds of plants and animals that must be preserved and protected.

By knowing the area, the forest and its contents and its benefits for the community and living creatures in the forest, it can stimulate the formation of a character that cares about the environment in Teruna Nyoman. The formation of a character that cares for the environment is very much needed, considering that until now, Tenganan Pegringsingan Village has been very strict with awig-awig to protect forest damage and the conversion of its 
environmental function is still being maintained. Without this awig-awig, the harmonious relationship between humans and their natural environment will be disrupted (Karmini, 2019, p. 163). Environmental conservation efforts are also shown by the existence of strict rules against cutting trees, even though the trees are privately owned by residents, there must be verification from the keliang adat, whether or not the trees are allowed to be cut (Sudiani, 2020, p. 141).

\subsubsection{Patience Character}

Patience is an attitude and behavior that shows the ability to control self-turmoil and survive as before and face various challenges or problems (Titib \& Sapariani, 2007, p. 114). The building of patience character in the Materuna Nyoman Ceremony is carried out through examples shown by the model, such as the patience of the daha when thrown with mud by the teruna during the Matimpugan. At the time, Matamyang and Malegar were also shown the patience of the teruna to wait for the daha's answer to be able to continue the Sambodana, as a form of apology for what had been done during Matimpugan.

By seeing, hearing and feeling the patience of the daha in restraint when being thrown by the mud and the patience of the teruna to get forgiveness from the daha, students will be able to imitate it. However, what is seen and heard will not be done automatically, but the results of those observations will be processed and transformed through actions as needed. This is consistent with what Santrock (2009, pp. 326-327) explains, that there are four processes that must be considered in learning, namely: attention, memory, production, and motivation. In this way, what the Teruna Nyoman sees and hears at the Matimpugan, Matamiang and Malegar events will be stored in their memory, but it will not necessarily be done like a model behavior, but it depends on the cognitive level and needs of teruna concerned. This opinion is reinforced by Hergenhahn \&
Olson (2017, pp. 360-361), that learning is cognitive, not reinforcement theories and information obtained through learning will only be followed up if there are compelling reasons to do so, such as when a need arises.

The character of patience must be possessed by every teruna so that no disputes arise, both during his education in the dormitory and in community life. Religion teaches that every people must have a patient nature. In Hinduism, patience is the nature of the gods or Daivi Sampad, as mentioned in Bhagavadgita XVI.2, (Pudja, 2004, p. 372)

\subsubsection{Character of Social Care}

Social care is an attitude and action that always wants to provide assistance to other people and communities in need (Samani \& Hariyanto, 2012: 52). The formation of the character of social care at the Materuna Nyoman Ceremony can be seen at the Ngejot katipat, Namyu-katamyu and Ngejot gede events, namely giving food to each other or entertaining each other, as a thank-you note for what has been given. What Teruna Nyoman does through the ceremony is a learning process through real activities, such as: entertaining Mekel who has provided education, entertaining daha and senior teruna who have guided during the ceremony through Ngejot katipat, Namyu katamyu and Ngejot gede events.

Through such social interactions, it can stimulate students' critical minds to know what is the meaning of everything that has been done, so their desire to ask questions arise and find the relationship between previous knowledge and what is experienced in the implementation of the ritual. In the end, Teruna Nyoman was able to construct new knowledge, especially an understanding of the importance of social caring attitudes and behaviors in social life, so that these attitudes and behaviors can be applied in social life. This is in accordance with social constructivism learning, which states that knowledge is created by learners through social interaction (Wardoyo, 2015, p. 24). Likewise Khoe (2015, p. 246), states 
that for social constructivists, learning is a social process that does not occur in individuals or is formed by external forces. Vygotsky also thinks that the social environment is very important for learning and social interactions can change or transform learning experiences (Schunk, 2012, p. 339).

Social care in Hinduism is found in the teachings of Catur Paramita, which is called Karuna, which is an attitude of compassion and likes to help others without asking for anything in return. The importance of having a social caring character is also based on the view that humans are not only an individual being but also a social being. This seems to be realized by the people of Tenganan Pegringsingan, so that social caring character education is also taught through social interactions at the Materuna Nyoman Ceremony.

Max's view of humans as social beings and consciousness is a causal claim about the weight of influence the social context has on various ideas and opinions, values and individual sentiments (Stones, 2012, p.112). Max's view can explain that the activities in the Meteruna Nyoman Ceremony carried out by the Tenganan Pegringsingan community are an effort to make teruna aware of the importance of a sense of social care. The Yajurveda XIX.51 also guides mankind to always provide assistance to people in need as a form of social care to save the lives of others (Titib, 1996, p. 332). The Upanisad mentions "Aham Brahman Asmi" which shows that every living creature comes from the same source, therefore everyone is obliged to develop an attitude of social care (Radhakrishnan \& Mantik, 2008, p. 122).

\subsubsection{Willing to sacrifice Character}

Willing to sacrifice is an attitude and behavior whose actions are carried out sincerely and willingly (Titib \& Sapariani, 2007, p. 101). In the teachings of Dasa Yama Brata, a self-sacrificing attitude is called Anresangsya, which is an attitude that is not selfish and has the soul to sacrifice one's own interests for the sake of common interests. The Upanisad teaches being willing to sacrifice, because all humans are the same which is called Tat tvam asi so that they should not prioritize the ego (Radhakrishnan \& Mantik, 2008, p. 353). In Hinduism, being willing to sacrifice that is done sincerely is called yadnya. Every living being should make sacrifices to others, the universe, ancestors, teachers and God.

In the Materuna Nyoman Ceremony, the character of being willing to sacrifice is taught through Teruna Nyoman's willingness to sacrifice playtime, comfortable sleeping at home, time to chat with parents because they have to live in a dormitory for one year, and so on. In addition, Teruna Nyoman is also taught to be able to do his yadnya, such as: being willing to sacrifice to others, which is manifested by always providing assistance to residents in need; willing to sacrifice to the teacher, shown by a willingness to carry out any task ordered by the teacher or mekel; being willing to sacrifice to the parents, is shown obeying the advice of the parents, that is, they are willing to follow the ceremony in the traditional village; sacrifice to nature, shown by preserving the nature around the village of Tenganan; and yadnya to God, shown by always devotional service by praying before, during and at the end of the activity to ask for blessing and as a thank you.

Sacrifices during the Materuna Nyoman Ceremony will be stored in the memory of each teruna and will be constructed into new knowledge that is able to shape the attitudes and behavior of teruna to always put the interests of others or society above their own interests. The 
ability of teruna to build their own knowledge is a reflection of Vigotsky's constructivist learning (Salkind, 2009, pp. 374-375).

\subsubsection{Independent Character}

Independence is an attitude and behavior that is not easily dependent on others to complete tasks (Mustari, 2017, p.77). According to Titib \& Sapariani (2007, pp. 77-78), independence is an attitude and behavior that relies more on awareness of one's own will, ability and responsibility without depending on others. In the Materuna Nyoman ceremony, the formation of an independent character is carried out through the Malali ritual, which is a ritual that is considered pingit, so it must be done at night and should not be known by other people. Ritual processions are also carried out by prospective teruna themselves, without involving other people. This shows that since the preparation ceremony for teruna candidates have been taught to live independently, not depending on other people to complete tasks. Apart from going through Malali, the formation of an independent character is also carried out by involving Teruna Nyoman in activities that are the task of teruna in traditional villages, such as ngejot, namely bringing food to village boarding houses, during ceremonies. During the ngejot, each Teruna Nyoman will get their own task, they are not allowed to ask for help from others.

What Teruna Nyoman does in the Malali ritual and ngejot is basically a learning process to form an independent character. Teaching children to always complete tasks on their own without the help of others can stimulate children to construct new knowledge, according to the experiences gained in interacting. In the end, attitudes and behaviors will be formed that are able to make teruna more capable on their own abilities in completing tasks, not depending on others. The success in forming an independent character is shown by the absence of a begging attitude shown by villagers to tourists who come to visit Tenganan Pegringsingan village (Sudiani, 2015, p. 60)

\subsubsection{Responsibility Character}

According to the Ministry of National Education's Balitbang Curriculum Center, responsibility is the attitude and behavior of a person to carry out duties and obligations, which must be done, towards oneself, society, the environment, the country and God Almighty. According to Titib \& Sapariani (2007, p. 54), being responsible is the attitude and behavior that dares to bear all the consequences of the actions or actions he has done, which are manifested in consistent and thorough behavior in carrying out something.

At the Materuna Nyoman Ceremony, the formation of the character of responsibility is carried out through the Malali ritual, by giving tasks that must be completed by prospective teruna as a condition of being able to attend further education. The task must be completed alone without involving parents. In this ritual, the older teruna are also responsible for leading and protecting the younger ones.

The character building of responsibility is also carried out through the obligations given to students while living in the dormitory, such as: looking after the subak, cleaning the subak, looking for water and turning on the subak lamp. On certain days Teruna Nyoman is also required to carry out mutual cooperation, such as cleaning the temple grounds, canals and so on. All of these obligations are carried out for one year, and if anyone violates them, they will be punished.

In addition to being assigned to a dormitory, Teruna Nyoman is also required to participate in activities in the youth organization (Sekeha Teruna). At this stage Teruna Nyoman has begun to be formed into an adult human who has a better mind than before and is able to build a sense of 
community. Teruna Nyoman also began to be involved in higher duties and responsibilities, being involved in carrying out the tasks of the Sekeha Teruna.

Looking at the explanation above, it can be interpreted that what Teruna Nyoman did both in the Malali ritual, while at the dormitory and at Sekeha Teruna was a learning process to shape the character of students' responsibility through practice in the field. The experiences gained through these activities will be imprinted and stored in the memory of each student, which will later be developed by each student according to their respective abilities. The ability of children to develop their knowledge and skills is a reflection of constructivism in Vigotsky's theory of development (Jamaris, 2010, p. 212)

\subsection{Implication of the Materuna Nyoman Ceremony on the attitudes and behavior of teruna}

What is meant by implication in this article is the direct or indirect impact or involvement of something. According to the Big Indonesian Dictionary, the implication is defined as involvement, or the state of being involved, but it is not clearly stated (Suharso \& Retnoningsih, 2017, p. 178). Referring to this definition, it can be said that the participation of teenagers in the Materuna Nyoman Ceremony has implications for the aspects of knowledge, attitudes and behavior of the cadets themselves. The implication for the knowledge aspect implies that the involvement of teruna in the Materuna Nyoman Ceremony turns out to be able to build student's knowledge about ethics, ceremonies, customs and environmental preservation in Tenganan Pegringsingan Village, as said by I Gede Bagus Adnyana (16 years). Among his several statements, he said:

......with Materuna Nyoman I became more aware of the life processes in Tenganan Pegringsingan, especially regarding culture that I previously did not understand and understood. Already understand the procedures for carrying out the ceremony, already know the environment $\&$ boundaries of Tenganan village. Understand ethics, such as: no noisy at night, no harsh words, no handling of friends' heads, respect for seniors, Mekel and elders (interviewed, 26 August 2020) What the student (Teruna Nyoman) said above, shows that after participating in the Materuna Nyoman Ceremony, students have been able to construct knowledge through experiences and social interactions that have been carried out during education, even though it is only limited to practical knowledge and has not touched on the philosophical meaning of education that hs been followed. This may be due to the limitations of the Teruna Nyoman in interpreting what they experienced during the ceremony, think of their young age. However, this can be a starting point for the development of teruna knowledge, which will continue to develop according to the age and activity of teruna in the community after completing education through the Materuna Nyoman Ceremony. This is in line with the views of constructivism, including Gagnon and Collay, that a constructive approach refers to the assumption that humans develop themselves by involving themselves in both personal and social activities in building science (Suda, 2018, p. 125).

Furthermore, the understanding of the teruna has implications for the attitude of the teruna themselves. This means that when students acquire knowledge about ethics, responsibility, social care, environmental care and so on, it has implications for the development of students' attitudes, marked by being patient, independent, tolerant, responsible, willing to sacrifice, social care, as a foundation of good character, as stated by I Gede Pathardika Pratama (16 years old). Among his several statements, he said:

......for me, Materuna Nyoman is something that is not easy, but very 
fun, like when ngintarang katekung, Helping senior teruna slice pork and making sate lilit was also great fun. I also feeling closer to friends, more ethical like not being noisy at night, not speaking harshly, not holding friends' heads, respecting seniors and always being respectful to Mekel. if it breaks I feel ashamed (interviewed, 25 August 2020)

What was conveyed by student above, shows that the development of positive knowledge will have implications for the formation of positive attitudes in students.

Furthermore, a good attitude in the end also leads to the development of good behavior for teruna who have participated in the Materuna Nyoman Ceremony, such as: teruna are used to living simply by sleeping in a simple place, accustomed to getting up early without having to be awakened, accustomed to work together, accustomed to behave politely, respect to one each other, accustomed to maintain cleanliness of the environment, behaving socially, being able to manage time and accustomed to carry out culture and religious activities which are the task of the teruna. This was said by I Gede Pathardika Pratama as follows:

.....since following the Materuna Nyoman Ceremony until now I have felt a change in myself, such as at first I was uncomfortable sleeping in an open space, without a mattress, using wooden pillows, now I'm used to it, used to sleep together, never saying rude words, never holding a friend's head, used to get up early, used to sweep, used to fetch water, accustomed to boost, used to make satay, already participating in cutting pork, brave maabwang and masmbodana, accustomed to make ceremonies, maintaining environmental cleanliness that I had never done before, and I feel more independent (interviewed, 25 August 2020).

What was said by the teruna above shows that after participating in the Materuna
Nyoman Ceremony there has been changes in attitude and behaviors of the teruna. So the changes can be interpreted as a positive implication of the Materuna Nyoman Ceremony on the attitudes and behavior of Tenganan Pegringsingan teruna.

\section{CONCLUSION}

First, the Materuna Nyoman Ceremony is a ritual used by the Tenganan Pegringsingan community to mature a child, meaning that a child has not been recognized as an adult before completing the Materuna Nyoman Ceremony, even though it is biologically considered an adult. Apart from being a ritual maturation, the Materuna Nyoman Ceremony is also believed to be an educational media to form teruna who are not only cognitively capable, but also have sradha and bhakti, have noble character, independent and responsible.

Second, character building through the Materuna Nyoman Ceremony is carried out through ceremonial phases, during dormitories and through activities in traditional villages. The characters that can be formed through the Materuna Nyoman Ceremony are: religious character, patience, tolerance, social care, environmental care, responsibility, independence and willing to sacrifice

Third, the participation of teenagers in the Materuna Nyoman Ceremony has implications for the aspects of knowledge, attitudes and behavior of the children themselves. The implications for knowledge can be seen from the increasing understanding of teruna about ethics, customs and environmental care. The implications of children's attitudes can be seen from the attitude that highly respects cultural values, mutual respect, responsibility, and care for others. Meanwhile, the implications for teruna behavior can be seen from changes in 
behavior, such as being accustomed to living simply, getting up early in the morning, accustomed to behave politely, respecting each other, accustomed to maintain cleanliness of the environment, social behavior such as accustomed to boost, being able to manage time, and accustomed to carry out the culture and religion activities which is the task of teruna in traditional villages.

\section{REFERENCE}

Arifin, B. S., \& Rusdiana. (2019). Manjemen Pendidikan Karakter. Pustaka Setia.

Arta, K. S., \& Yuliartini, N. P. R. (n.d.). Kearifan Lokal Sebagai Modal Dalam Pendidikan Karakter (Studi Kasus Dalam Tradisi Materuna Nyoman di Desa Tenganan Pegringsisngan, Karangasem, Bali). https://www.academia.edu/15183608 /Kearifan_lokal_sebagai_modal_bud aya_dalam_pendidikan_karakter_stu di_kasus_dalam_tradisi_materuna_n yoman_di_desa_tenganan_pagerings ingan_karanagasem_bali

Dillon, M. (2012). Sosiologi Agama. In B. S. Turner (Ed.), Teori Sosial Dari Klasik Sampai Postmodern (p. 968). Pustaka Pelajar.

Durkheim, E. (2011). The Elementary Forms Of The Religious Life (E. A. . Iyubenu \& A. Fahrudin (eds.); Baru). IRCiSoD.

Hergenhahn, B. R., \& Olson, M. H. (2017). Theories of Learning (Teori Belajar) (Ketujuh). Kencana.

Jamaris, M. (2010). Orientasi Baru dalam Psikologi Pendidikan. Yayasan Penamas Murni.

Karmini, N. W. (2019). Model Pendidikan Lingkungan Hidup Bagi Generasi Melenial Pada Era 4.0 (Kasus Pengelolan Hutan Di Desa Adat Tenganan). Jurnal Penelitian Agama Hindu Institut Hindu Dharma Negeri Denpasar Volume 3 Nomor 2 (2019)
ISSN : 2579-9843 (Media Online), 3(2), 158-167. https://doi.org/ 10.25078/jpah.v3i2.1080

Khoe, Y. T. (2015). Pembelajaran dan Perkembangan Belajar (B. Sarwaji (ed.); Bahasa Ind). Indeks.

Koentjaraningrat. (2007). Sejarah Teori Antropologi I. UI-Press.

Koentjaraningrat. (2014). Pengantar Antropologi I. Rineka Cipta.

Koesoema, D. (2012). Pendidikan Karakter Utuh dan Menyeluruh (Erdian (ed.)). Kanisius.

Lickona, T. (2012). Educating for Character (How our Schools Can Teach Respect and Responsibility) (U. Wahyudin (ed.); 1st ed.). PT. Bumi Aksara.

Miles, M. B., \& Huberman, A. M. (1992). Anaisis Data Kualitatif: Buku sumber tentang Metode-Metode Baru. UIPress.

Mishra, P. ., Paramita, I. G. A. D., \& Pandewi, D. S. (2008). Hindu Dharma: The Universal Way Of Life Tejemahan (I. K. Donder (ed.); Pertama). Paramita.

Moleong, L. J. (2010). Metodologi Penelitian Kualitatif (Edisi Revi). PT. Remaja Rosdakarya.

Mulyasa, H. (2011). Manajemen Pendidikan Karakter (Dewi Ispurwanti (ed.)). PT Bumi Aksara.

Mustari, M. (2017). Nilai Karakter Refleksi untuk Pendidikan (M. T. Rahman (ed.); 1st ed.). Rajagrafindo Persada.

Pals, D. L. (1996). Seven Theories Of Religion (1st ed.). Oxford University Press.

Pudja, G. (2004). Bhagavad Gita (Pancama Veda). Paramita.

Radhakrishnan, S., \& Mantik, A. S. (2008). The Principal Upanisads (Pertama). Paramita.

Salkind, N. J. (2009). Teori-Teori Perkembangan Manusia: Sejarah Kemunculan, Konsepsi Dasar, Analisis Komparatif, dan Aplikasi. Nusa Media.

Samani, M., \& Hariyanto. (2012). 
Pendidikan Karakter. Remaja Rosdakarya.

Santrock, J. W. (2009). Psikologi Pendidikan (Educational

Psychology), buku 1 (R. Oktafiani (ed.); 3rd ed.). Salemba Humanika.

Schunk, D. H. (2012). Learning Theories: An Educational Perspective (teoriteori Pembelajaran: Perspektif Pendidikan) (R. Indriani (ed.); Keenam). Pustaka Pelajar.

Schwartz, A. J., Sommer, C. H., Berkowitz, M. W., Walker, L. J., Sherman, N., Etzioni, A., Power, F. C., Colby, A., \& Kristol, I. (2002). A Communitarian Position on Character Education. In W. Damon (Ed.), Bringing In A New Era In Character Education (First, p. 211). Hoover institution Press.

Śivānanda, Ś. S. (1997). All About Hinduism (Intisari Ajaran Hindu) (Pertama). Paramita.

Stake, R. E. (2010). Qualitative Research Studying How Things Work. The Guilford Press.

Stones, R. (2012). Tindakan, Aktor dan Sistem. In B. S. Turner (Ed.), Teori Sosial Dari Klasik Sampai Postmodern (p. 968). Pustaka Pelajar.

Suda, I. K. (2018). Membentuk Karkter Anak melalui Seni Melukis (Studi Analisa pada "I Wayan Gama Painting School" di Desa Keliki, Tegallalang, Gianyar) (I. G. K. Widana (ed.); Pertama). PT. Japa Widya Duta.

Sudiani, N. N. (2015). PENDIDIKAN KARAKTER MELALUI GENDING RARE STUDI ETNOGRAFI PADA ANAK USIA DINI DI DESA ADAT TENGANAN PEGRINGSINGAN, KABUPATEN KARANGASEM, PROVINSI BALI (2013). Jurnal Pendidikan Anak Usia Dini, 9(1), 5174.

https://doi.org/10.21009/JPUD.091.0 4

Sudiani, N. N. (2017). PEDANDA BAKA STORY AS MEDIA OF
CHARACTER EDUCATION SINCE EARLY CHILDHOOD. Vidyottama Sanatana: International Journal of Hindu Science and Religious Studies, 1(1), 8.

Sudiani, N. N. (2020). Pencegahan Wabah Covid-19 melalui Pendidikan Karakter Peduli Lingkungan pada Anak Usia Dini. In K. A. P. Dewi \& J. Simarmata (Eds.), Covid-19: Perspektif Pendidikan (1st ed., p. 17). Yayasan Kita Menulis.

Suharso, \& Retnoningsih, A. (2017). Kamus Besar Bahasa Indonesia (Lux). V. WIdya Karya.

Syarif, E., Hasriyanti, Fatchan, A., Astina, I. K., \& Sumarmi. (2016). Conservation Values of Lokal Wisdom Traditional Ceremony Rambu Solo Toraja's Tribe South Sulawesi as Efforts the Establishment of Character Education. EFL JOURNAL, Volume 1((1), 2016), 1723.

https://www.efljournal.org/index.php /efljournal/article/view/6

Titib, I. M. (1996). Veda Sabda Suci (Pedoman Praktis Kehidupan) (1st ed.). Paramita.

Titib, I. M., \& Sapariani, N. K. (2007). Pendidikan Budhi Pekerti dan Keutamaan Manusia. Paramita.

Wardoyo, S. M. (2015). Pembelajaran Konstruktivisme (Teori dan Aplikasi Pembelajaran dalam Pembentukan Karakter) (Kedua). AlfaBeta. 